\title{
BETWEEN THE FRONT LINE AND THE REAR: THE POSITION OF THE JEWISH EVACUEES OF THE FIRST WORLD WAR IN EASTERN SIBERIA IN THE RUSSIAN EMPIRE
}

\author{
TATYANA KATTSINA* \\ LUDMILA MEZIT**
}

\section{Introduction}

The participation of Russia in the First World War caused mass flight within the country. Most refugees came from the front in the western part of the country. The 'Law for the provision of refugees' necessities' dated 30 August 1915, regulated various aspects of the phenomenon, and defined refugees as 'people who left the places under the enemy's menace or occupied by the enemy, either evacuated under the regulation of the military or the civil authorities from the military action area, as well as immigrants from Russia's public enemies.' ${ }^{\prime}$ Thus, the term 'refugees' included a wide 'variety of members,' ${ }^{2}$ i.e. those who left boundary provinces of their own accord, who did not want to stay on the front line or in the territories under occupation; those from areas dismantled by government order on the retreat of Russian troops; families of the officials in civil and rear military institutions, evacuated to the east of the country; those evacuated from areas near the front and separate ethnic groups who were considered by military leaders to be the enemy's diversionary potential and reserve in the event of the Russian troops' retreat. At the same time, the law did not identify those displaced under police supervision as refugees. ${ }^{3}$

The question at issue was that the majority of refugees could be separated into those displaced by government order and those who escaped from war by their own free will. ${ }^{4}$ Meanwhile, 'refugee' status gave a right to

\footnotetext{
* Siberian Federal University, Russian Federation; Krasnoyarsk State Pedagogical University named after V. P. Astafev, Russian Federation; e-mail: katsina@list.ru.

${ }^{* *}$ Krasnoyarsk State Pedagogical University named after V. P. Astafev, Russian Federation; e-mail mezit@yandex.ru.

1 Законы и распоряжения о беженцах, Выпуск первый (Москва: Городская типография, 1916), 2.

2 Беженцы и выселенцы. Отдельные оттиски из номера 17 Известий Всероссийского Союза Городов (Москва: Московская городская типография, 1915), 1.

3 Законы и распоряжения о беженцах, 2.

4 Лев Гальперин, “Обязательное призрение и помощь беженцам”, Призрение и благотворительность в России, по. 5 (1915): 529; Беженцы и выселенцы, 1; “Новая ссылка (из Нарымского края)," Сибирь, 11 января 1915, 2; Борис Опальный, “Выселенцы,” Иркутская жизнь, 15 декабря 1915, 2.
} 
social assistance determined by a number of regulations, ${ }^{5}$ and the 'displaced person' status gave the right to receive the same allowance as government deportees.

Since the presence of refugees and displaced people is indicative of the frequency and intensity of armed conflicts, it is worth paying attention to their quantitative characteristics. Consolidated figures turned out to be most significant in the Russian Empire where, by July 1917, refugees numbered about 7.4 million. ${ }^{6}$ According to the English historian Peter Gatrell, the Russian refugees of the First World War numbered around 6 million $(5 \%$ of the country's population) which was twice as high as the number of industrial proletariat and three times as high as the number of the Russian military war dead. ${ }^{7}$ According to Nikolai Mikhalev and Stepan Pyankov, national statistics give 'only approximate degree of fleeing that could involve from 5 up to 15 million people, having turned into one of the factors of the growing socioeconomic and political crisis in the country.'

The large-scale dislodgement of 'whole nations: the Poles, the Lithuanians, the Latvians, '9 gave a 'national' character to the Russian flight of 1914-1918. A rough estimation of the Jews displaced from their permanent residence, according to various sources, ranges from '200 up to 600 thousand and even up to 1 million people.' ${ }^{10}$

The inadequate response of the government to various ethnic groups of refugees seriously complicated the problem of their integration, since they took different places in the hierarchy of 'reliable' as against 'suspicious' nationalities. It is well-known that at the very bottom of this hierarchy were the Germans and the Jews, suspected of political disloyalty and espionage and, consequently, rendered victims of a genuinely discriminatory policy. ${ }^{11}$

\footnotetext{
5 Законы и распоряжения о беженцах, 1-7; 9-11; Руководящие положения по устройству беженцев (Петроград: Типография Министерства внутренних дел, 1916), 1.

${ }^{6}$ Наталья Суржикова Николай Михалев и Степан Пьянков, "Российское беженство 1914 1922 годов а контекстах новейших отечественной и зарубежной историографий,” Вестник Пермского университета 20, Выпуск 3 (2012): 141.

${ }^{7}$ Peter Gatrell, $A$ Whole Empire Walking: Refugees in Russia during World War I (Bloomington \& Indianapolis: Indiana University Press, 1999), 3.

${ }^{8}$ Николай Михалев и Степан Пьянков, "Беженцы Первой мировой войны в Российской империи; численность, размещение, состав,” Уральский исторический вестник 49, по. 4 (2015): 103.

9 Стенографический отчет. Государственная Дума. Четвертый созыв. Сессия IV. Заседание десятое. Пятница, 14 августа 1915 г. ([Петроград]: Государственная типография, [1915]), 809, 814; дата обращения 20 марта 2019, https://naukaprava.ru/catalog /3355/335690/3356905/36603?view=1.

10 Анастасия Туманова, Общественные организации России в годы Первой мировой войны (1914 - февраль 1917 г.) (Москва: Политическая энциклопедия, 2014), 225.

${ }^{11}$ Суржикова, Михалев и Пьянков, “Российское беженство 1914-1922,” 142.
} 
The American historian, Eric Lohr, characterised the forced migration of the Jews in Russia, not only as the largest migration during the First World War, but also as maleficent. ${ }^{12}$ He emphasised that the forced eviction of the Jews 'differed from similar measures taken with regards to other population groups by a whole range of features. ${ }^{13}$

Since the problem of meeting the refugees' basic survival needs is directly connected with the question of the provision of social care for them, this article addresses two interrelated issues: firstly, it describes the Jews' position as they were evacuated into Eastern Siberia during the Imperial period of the First World War; secondly, it examines the measures taken by the government and public organisations to provide social support. The development of these issues touches on humanitarian and ethnic aspects of flight, and fits into the context of accompanying regional studies. ${ }^{14}$

The Eviction of the Jews from the Military Action Areas to Eastern Siberia: Aspects of Organisation and Adaptation

European Russia was main recipient of refugees, taking in approximately $85 \%$ of all refugees. ${ }^{15}$ Nevertheless, it should be born in mind that incapacitated refugees were evacuated to the eastern areas, including Siberia, as these territories offered 'most capacity to fulfil assistance functions,' 16 and received the victims of forced evictions and deportations.

Displaced people started coming to Siberia in the autumn of 1914, initially in small groups, and from April 1915, after the retreat of the Russian

\footnotetext{
12 Eric Lohr, "The Russian Army and the Jews: Mass Deportation, Hostages, and Violence during World War I," The Russian Review 60, no. 3 (Jul., 2001): 404-419.

13 Эрик Лор Русский национализм и Российская империя: Кампания против «вражеских подданных» в годы Первой мировой войны, пер. Владислава Макарова (Москва: Новое литературное обозрение, 2012): 163.

14 Анна Щетинина, “Беженцы и гражданские интернированные на юге Западной Сибири (1915-1920-е гг.)”, Известия Алтайского государственного университета 56, no. 4-2 (2007): 177-182; Александра Кузьменко, "Недобровольные мигранты в Восточной Сибири в $1914-$ феврале 1917 гг.: на примере Енисейской и Иркутской губерний” (диссертация кандидата, Институт монголоведения, буддологии и тибетологии Сибирского отделения Российской академии наук (Улан-Удэ), 2010); Татьяна Катцина, “'Нуждаемся во всем...': положение выселенцев Первой мировой войны в Восточной Сибири,” Вестник Красноярского государственного педагогического университета имени В. П. Астафьева 26, no. 4 (2013): 219-222; Наталья Орехова и Яков Кофман, Еврейские общины на территории Енисейской губернии (XIX-начало 30-Х гт. XX вв.) (Красноярск : Красноярский писатель, 2009).

15 Михалев и Пьянков, “Беженцы Первой мировой войны”, 102.

${ }^{16}$ Беженцы и выселенцы, 27.
} 
army, in droves ${ }^{17}$ from the Grodnenskaya, Vilenskaya, Volynskaya, Minskaya, Kurliandskaya, and Kovenskaya Provinces.

Eviction was based on charges of spying, aiding the military enemy, or spreading rumours against the Russian army. Many people were arrested as a result of false denunciations from personal enemies or an abuse of rights by the local administrative authorities. ${ }^{18}$ It was not infrequent that a court-martial would discharge a person, who would nevertheless be sent to Siberia on account of an administrative court decision already made. ${ }^{19}$

The eviction of the Jews was a mass expulsion and was complicated by a number of circumstances. The Jews were given no notice; nobody took into account the fact that fathers and sons were serving in the field or in army hospitals. ${ }^{20}$ They were given just 36 (and sometimes even less than 24) hours to pack. People walked on foot, with their hastily packed possessions in their own carts, at best. They came from a variety of social groups and, displaced by an administrative procedure, they moved on with travel permits, ${ }^{21}$ under police escort, at their own expense. ${ }^{22}$

Initially, the displaced people were directed to Tomskaya Province (in Western Siberia) and housed in basic accommodation in Narymskiy Krai (the centre of political exile in the north of the province), mostly in its most isolated and far-flung parts. In January 1915, the krai hosted 1,000 evacuees, in comparison with a maximum of 200 persons during $1914 .{ }^{23}$

In the spring and summer of 1915, the direction of the evictions moved to Yenisseyskaya Province ${ }^{24}$ and, in the autumn of 1915, to Irkutskaya Province. ${ }^{25}$ By December 1915, the Иркутская жизнь newspaper was already announcing that, together with a crew of prisoners, every Sunday a significant number of displaced people arrived from Russia into the custody of the governors of Siberia. ${ }^{26}$ After two or three months of compulsory transportation, they stayed in local transit prisons for one month on average. In the overcrowded cells, together with criminals one could see '7-year boys' and 14-

\footnotetext{
17 Российский государственный военно-исторический архив (РГВИА), фонд 13273, опись 1 , дело 49, лист 10; “Сибирское обозрение,” Сибирь, 30 декабря 1914, 3.

18 Война и евреи. Дело о шпионстве. Выселение (Иркутск: элетротипография А. Белоногова, 1915), 54; РГВИА, фонд 13273, опись 1, дело 49, лист 1-4, 28 оборот, 31-32.

19 Ibid., лист 1-4.

20 Война и евреи, 54-56.

${ }^{21}$ They had a special identity card (Pass Certificate) during the journey to the place of exile.

22 РГВИА, фонд 13273, опись 1, дело 49, лист 9-10.

23 “Новая ссылка (из Нарымского края)," 2.

${ }^{24}$ Administrative and territorial entity of the Russian Empire, founded on 22 July 1822, at the division of Siberia into West Siberia and East Siberia. The administrative centre is Krasnoyarsk City.

25 Administrative and territorial entity of the Russian Empire, founded on 19 October 1764, situated in East Siberia. The administrative centre is Irkutsk City.

26 Опальный, "Выселенцы," 2.
} 
year-old high school girls. ${ }^{27}$ Later the displaced people with escort guards were transferred to the control of district police officers. They had to walk without carts for 300-1,000 verst (approximately $320-1,100 \mathrm{~km}$ ) and more. ${ }^{28}$ Provincial authorities, obeying a special circular order, deliberately assigned the displaced people to outlying points of Yenisseyskaya Province (Yenisseyskiy District, Turukhanskiy Krai) and Irkutskaya Province (Kirenskiy, Verkholenskiy, Nizhneudinskiy and Balaganskiy Districts). ${ }^{29}$ Those who were settled in the Kirenskiy District faced the most severe problems: in winter, the route to the district passed through the Aleksandrovskaya transit prison, where the displaced people had to stay, as if prisoners, until late spring. ${ }^{30}$

Together with the influx of refugees, anti-Jewish posters, leaflets, brochures proliferated in Siberian cities, and the belief in a mass Jewish participation in extreme left-wing political parties grew strong. To a certain degree, anti-Semitism increased because the refugees from the European part of the country brought to Siberia their negative attitude to the Jews. ${ }^{31}$

The practice of the eviction of people considered to be security risks happened at such a fast rate that neither administrative bodies, nor committees for the assistance of refugees, nor even the powers who issued the eviction orders to Siberia, had the time or opportunity to estimate degree of danger represented by a particular displaced person. Eviction orders detailed the reasons and offences causing their issue but were not given to the displaced people, and were often followed by letters dismissing the charges that had served as a reason for eviction. This made correct classification of the displaced people difficult and caused significant confusion. Occasionally, people who had already gone through all the nightmares of the journey as a prisoner, and reached their destination, returned from their exile. ${ }^{32}$ According to the reports of the Authorized Representative of the All-Russian Cities Union on the displaced people, $75 \%$ of those exiled to Irkutskaya and Yenisseyskaya Provinces did not pose any threat to the state..$^{33}$

As civil deportees, the displaced people had a right to a state monthly allowance, the amount of which depended on where they were resident. Thus, in the Yenisseyskiy District of Yenisseyskaya Province it was set at the sum of 8 roubles, ${ }^{34}$ and in Irkutskaya Province from 8.6 to 9.5 roubles..$^{35}$ This money was

\footnotetext{
27 РГВИА, фонд 13273, опись 1, дело 49, лист 14.

28 Ibid., лист 11, 18-19.

${ }^{29}$ Ibid., лист 11.

30 Опальный, "Выселенцы," 2.

31 Война и евреи, 52; РГВИА, фонд 13273, опись 1, дело 152, лист 21-21 оборот.

32 Опальный, “Выселенцы," 2; “Новая ссылка (из Нарымского края),” 2; РГВИА, фонд 13273, опись 1 , дело 49 , лист 1 .

33 Ibid., лист 12.

34 “Совещание о беженцах," Сибирь, 25 ноября 1915, 1.
} 
not sufficient, given local prices. In the Verkholenskiy District, for example, a pound $^{36}$ of brown bread cost 7 kopeks (0.07 roubles), of white bread 11-12 kopeks (0.11-0.12 roubles), and of meat 25-30 kopeks (0.25-0.30 roubles); monthly room rent was $10-15$ roubles. Most displaced people did not receive any allowance, despite numerous requests and pleas. Occasional fortunate ones received their allowance after delays of two to three months (Verkholenskiy District), ${ }^{37}$ six to eight months (Yenisseyskiy District) and even more elsewhere. ${ }^{38}$

It is worth noting that at local level, practices evolved for the provision of allowances which treated applicants of officially the same legal status in different ways. In the Balaganskiy District, for example, each evacuee received 16 roubles per month, whereas in the neighbouring Verkholenskiy District either special rules were applied or the rules were interpreted in a different way, for none of the displaced people in Verkholensk (7 persons) or Zhigalov (17 persons) received the allowance. Out of 109 refugees in Znamenka only 16 could exercise their right to the allowance. In Kachuga only 3 out of 34 persons received an allowance: one received 12 roubles, another 6 roubles, and the last one 3.6 roubles. In the settlement of Manzurka the allowance was only half the established amount, and it was given to only 12 displaced people out of $23 .{ }^{39}$

One further point deserves attention: while under arrest or travelling in convoy to Siberia, the displaced people had to hand the allowances into the offices of the various prisons in which they were held, since they had lost their right to hold money. The withheld money was sent to the destination, but generally with a delay of five to six months, which worsened the evacuees' already distressful situation.

Most of those who arrived at their place of exile gave a very sad impression of their helplessness; they could not speak Russian. After five to six months of the travelling as prisoners, they found themselves in a totally unfamiliar situation, torn from their homes, without any means of making a living. Many of them could not count on help from relatives, having lost contact with them.

The displaced people were placed in far-flung taiga settlements, which were overcrowded with the exiled, and where even relatively able-bodied people could not depend on any earnings. Among the evacuees were women, old men, and dependent exiled children, and people who had been

\footnotetext{
35 “Выселенцы в Верхоленском уезде," Сибирь, 13 августа 1916, 2.

${ }^{36}$ One pound equals 409.5 grams.

37 “Выселенцы в Верхоленском уезде," 2.

38 "Енисейское Общество пособия бедным евреям, действующее совместно с хозяйственным правлением Еврейского общества по оказанию помощи выселенцам евреям в Енисейском уезде," Вестник Приенисейского края, 17 июля 1916, 13.

39 "Выселенцы в Верхоленском уезде," 2.
} 
comparatively prosperous and had never lived in misery before. With the high cost of living, these people were 'in desperate need of everything. ${ }^{\prime} 0$ The evacuees arrived in exile with a particular social stigma and, with few exceptions, they did not attract any sympathy from the local population, and did not get, or could not rely upon, any support from them. ${ }^{41}$ The representatives of the Siberian communities who were involved in the solving the problems caused by the flight noted that 'due to the limited food resources, displaced people were an intolerable burden for the local population. ${ }^{42}$ The $319^{43}$ Jews who were exiled to the Yenisseyskiy District, which suffered crop failure in 1915, found themselves in an extremely hard situation. It was 'impossible to get bread even for money' there. ${ }^{4}$

\section{Assistance to the Displaced Jews from Public Institutions}

The question of those evacuated from the battle areas was examined particularly at a meeting held on 21-23 November 1915, in Irkutsk. The event was initiated by the Irkutsk Committee of the All-Russian Union of Cities, with the aim of developing an overall plan, rather than the uncoordinated measures then in place, for the organisation of assistance to refugees. Those present included the secretariat manager to the Irkutsk Governor General, civil servants from the Irkutsk Provincial and Migration Divisions, and the assistant supervisor of the migrants' movement (Eastern region), and the whole Irkutsk Town Council, headed by the mayor, represented the local authorities at the meeting. There were also representatives of Committees for the Assistance to Refugees from the towns of Achinsk, Krasnoyarsk, Mysovsk, Verkhneudinsk, Chita and Nerchinsk, and the settlement of Usolye, as well as members of Chita Regional Committee, Irkutsk Provincial Committee, Irkutsk Diocesan Committee and Irkutsk Jewish Committee for the Assistance of Refugees. The refugees were represented by 23 of their number, and local organisations that had various relations to the flight issue also took part in the meeting. Thus, the following associations delegated their authorized representatives: Mysovskiy Women's Circle, the Nizhneudinskiy department of the Siberian Society of Assistance to Sick and Wounded Soldiers and War Victims; the Krasnoyarsk and Yenisseysk Societies for the Support of Poor Jews; the Kansk and

\footnotetext{
40 РГВИА, фонд 13273, опись 1, дело 49, лист 16-19; “Выселенцы в Верхоленском уезде,” 2;

“Енисейское Общество," 13.

${ }^{41}$ РГВИА, фонд 13273, опись 1, дело 49, лист 7-8.

42 "О помощи выселенцам," в Протоколы совещания по вопросам призрения беженцев, состоявшегося 21-23 ноября 1915 г. в Иркутске (Иркутск: электро-типография И. А. Белоголовова, 1916), 89.

43 “Енисейское Общество," 13.

44 РГВИА, фонд 13273, опись 1, дело 49, лист 8; “Совещание о беженцах," Сибирь, 22 ноября 1915, 1.
} 
Krasnoyarsk departments of the All-Russian Union of Cities; the Irkutsk Department of the Russian Red Cross Society; Irkutsk Latvian Society 'Dzimtene'; and the Irkutsk Department of the Polish Society of Assistance to War Victims. ${ }^{45}$

On the basis of the arguments put forward by V. G. Distler (representing the Irkutsk Committee of the All-Russian Union of Cities) ${ }^{46}$ the meeting adopted the following resolution on the question of assistance to displaced people:

1) Taking into consideration that the displaced people fall under the control of local provincial authorities, it is imperative that the government does not place them in detached points, but in rural and town centres. [...] 2) Taking into account that the displaced people come without charge or trial and do not even know the reasons for their eviction for the most part, in our opinion, all the cases of the displaced people should be revised. 3) Due to the fact that among the displaced people who already arrived or are about to arrive in Irkutskaya and Yenisseyskaya Provinces there is a significant number of foreign subjects evacuated from Galicia and since part of such evacuees from European Russia are already sent back to their motherland, it is also necessary to return foreignnation displaced people from Siberia to their homeland, as far as possible. ${ }^{47}$

Despite this, eight months after the meeting, in July 1916, the Committee of the Siberian Society of Assistance to Sick and Wounded Soldiers and War Victims reported that 'the resolution was not put into motion yet.' 48

National charitable organisations played a prominent part in the life of the displaced Jews, adapting their work from the start of the war. Thus, the Irkutsk Department of the Jewish Population Health Keeping Society transformed into the Irkutsk Jewish Committee for the Assistance to Refugees 'in the light of the events. ${ }^{49}$ It arranged meal and lodging houses for the Jews evicted from those areas near the frontline and the rear throughout their journey. It also helped with their hygiene needs and gave them material and financial support. By 1 November 1915, 395 persons had received help of various kinds and amounts from the organisation, and the majority of these people were displaced..$^{50}$

The Yenisseysk Society for the Support of Poor Jews ${ }^{51}$ was essentially the first organisation to which displaced Jews applied on their arrival in the

\footnotetext{
45 “Совещание о беженцах," Сибирь, 22 ноября 1915, 2; “Совещание по вопросу призрения беженцев," в Протоколы совещания, I-IV, 3-4.

46 “Совещание о беженцах," Сибирь, 26 ноября 1915, 2.

47 “О помощи выселенцам," 89.

48 "Сибирское общество помощи больным и раненым воинам и пострадавшим от войны," Вестник Приенисейского края, 17 июля 1916, 12.

49 Tatiana Anatolievna Kattsina, “The 'Vast Process of Social Construction' in Siberia during World War I (1914-1918)", Terra Sebus. Acta Musei Sabesiensis, Special Issue (2014): 249.

50 “Первый день - 21 ноября. Утреннее заседание," в Протоколы совещания, 18.

${ }^{51}$ Established by the Jewish community in 1906.
} 
Yenisseyskiy District. In the beginning of summer 1915, because of the growing flow of displaced people, their large number and 'awful situation,' the Society regarded it to be 'its sacred obligation'52 to come to their aid, although it was beyond its jurisdiction. The Society widened its remit of work on the basis of permission given by the Yenisseyskiy Governor, but its activity was strictly limited by rendering aid only to the Jews. ${ }^{53}$ At the same time the Polish and Latvian organisations registered in Eastern Siberia could render assistance to representatives of different nationalities and ethnic groups. ${ }^{54}$

At the end of August 1915, the General Service Board of the Jewish Society for the Assistance of the Displaced Jews in Yenisseyskiy District (GSB) was formed to work together with the Yenisseysk Society for the Support of Poor Jews. The GSB financial report for August-October of 1915 gives a picture of revenue sources. Thus, all the reserve capital of the Yenisseysk Society for the Support of Poor Jews, collected during the previous ten years, was spent to meet the needs of the displaced Jews. GSB membership fees in September and October 1915 added more than 300 roubles in total and, within the same period of time, one-off donations amounted to 920 roubles. Almost all the members of local Jewish community gave a donation, and at the same time they also collected clothes. ${ }^{55}$

From the reports delivered by authorized officials on their return from the nearest volosts (areas) of the Yenisseyskiy District, it can be seen that the evacuees' needs were 'so enormous, that it did not seem possible to meet them by the local efforts and at the local expense. ${ }^{56}$ Extra financing came from Irkutsk Society for the Support of Poor Jews (500 roubles), the Society for the Support of Poor Jews (200 roubles), a private person from Minusinsk (100 roubles), and a large donation from the Petrograd Jewish Committee for the Assistance of War Victims (15,000 roubles). ${ }^{57}$

This money was used to arrange financial, material and food assistance to the displaced people (Fig. 1).

\footnotetext{
52 “Енисейское Общество," 13.

${ }^{53}$ Ibid., 14.

54 “Первый день - 21 ноября. Утреннее заседание," в Протоколы совещания, 21; РГВИА, фонд 13273, опись 1 , дело 49, лист 9.

55 “Енисейское Общество," 13.

56 Ibid., 14.

${ }^{57}$ Ibid., 15.
} 


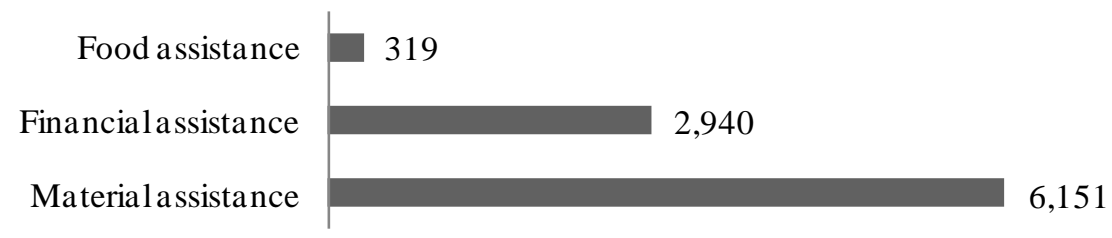

Fig. 1. Structure of Types of Assistance to the displaced Jews, and General Service Board of the Jewish Society for the Assistance of the Displaced Jews spending

(August - October 1915), roubles $^{58}$

Warm clothes and under-linen for the evacuees were made using the GSB's own resources. They bought all the necessary materials and gave them to the manufacturers, helping to lower the average cost. Some clothes were made for free by female members of the Yenisseysk Society for the Support of Poor Jews. It is important to note that, to administrate the Yenisseyskiy District, authorized representatives had to cover 900-2,000 verst $(960-2,140 \mathrm{~km}$ ) wasting between 19 and 30 days. The situation was complicated by the lack of human and material resources and by the muddy seasons, so vital warm clothes for the evacuees in the isolated and hard-to-reach regions (e.g. Turukhanskiy Krai and Angarskiy Krai) were sent by post or taken by private individuals. At the beginning of November 1915, financial and material assistance for an overall amount of 6,675 roubles was delivered to those regions, and nine released persons received 275 roubles for departure. ${ }^{59}$

In addition, the authorized representatives of the Yenisseysk Society for the Support of Poor Jews met each group of displaced people arriving in Yenisseysk, and provided them with basic necessities.60 The Krasnoyarsk Society for the Support of Poor Jews did similar work, rendering assistance to 75 displaced Jews who stayed in transit prison, providing them with warm clothes (to the amount of 533 roubles) and arranging a delivery of hot meals twice a week (at a cost of 10 to 12 roubles). ${ }^{61}$

Assistance arrangements included meeting not only organisational and financial challenges, but also moral and psychological difficulties. Thus, notwithstanding the clear need, the Yenisseysk Society for the Support of Poor Jews did not provide a meal station for the displaced people for moral reasons. The activities of the Society were restricted to Jews, and its organizers found it

\footnotetext{
${ }^{58}$ Ibid.

59 Ibid., 14; Протоколы совещания, 29.

60 “Енисейское Общество," 14.

61 Государственный архив Красноярского края, фонд 595, опись 50, дело 4724, лист 40.
} 
immoral to feed Jews in a separate room with any sort of comfort, while displaced people of other nationalities had to take meals in a prison ward.$^{62}$

The volunteers' efforts to end deportation to the Yenisseyskiy District and to make the state allowance payment to those evacuated under administrative procedures proved to be practically fruitless. ${ }^{63}$ Even the orders of the Governor General of Irkutsk on the immediate payment of the allowance to the displaced people were not carried out; new lots of those displaced from the frontline and areas near the rear continued to arrive in the district. ${ }^{64}$

Notwithstanding the difficulties connected with the work of local public organisations with displaced people, they succeeded in protecting the displaced Jews from physical degradation. At the same time the phenomenon of the flight of the Jews contributed to raise local awareness in the Jewish communities above all. They adjusted the aims of their organisations to the need to render assistance to the displaced people (Irkutsk Jewish Committee for the Assistance of Refugees, Yenisseysk Society for the Support of Poor Jews, Krasnoyarsk Society for the Support of Poor Jews) or created new structures (GSB). The existence and work of national charity organisations was determined by the presence of efficient organisers belonging to particular ethno-cultural groups in particular locations.

\section{Conclusions}

We can summarise the intermediate results as follows. The Jews evacuated from the frontline and areas near the rear during the First World War represented an economically, socially, psychologically and politically vulnerable population group. The violent and illegal character of the eviction itself was exacerbated by physical, material and moral deprivation, which often worsened due to organisational problems and the abuse of power by public authorities. The departure of the evacuees to the distant and isolated parts of Eastern Siberia was accompanied by serious physical hardships. The eviction campaign did not just condemn people to a sudden decline in financial standing, but made the majority live literally on the edge of starvation. The position of families was worsened psychologically, since many families were broken up or lost members on the orders of the state.

Induced to leave their homes, the displaced people found themselves in unfamiliar conditions with no shared means of sustenance. They were settled in isolated or economically undeveloped regions, which limited their employment opportunities and left them dependent on public assistance.

\footnotetext{
62 Протоколы совещания, 30.

63 “Енисейское Общество," 14.

64 РГВИА, фонд 13273, опись 1, дело 49, лист 5-5 оборот.
} 
The poor living conditions created problems with health, a restricted private life and broken family relationships. Associations that accepted displaced people could not give them proper support, since most of the local people were also among the most vulnerable population groups. An absence of coordinated action between state and public structures regarding this issue was a further obstacle to the immediate and efficient solution of the problems. As a result of administrative evictions, which were mostly unfounded, social groups suffered discrimination. In general, the strategy of the majority of the displaced people in the territory of Eastern Siberia during the First World War was one simply of survival. 
Degtev S. I. Reform of the monetary system in NEP Russia // Monetary reforms in Russia: history and modernity: collection of articles.

Children and the court // Krasnoyarsk worker. 1920.29 February S. 3

Children-criminals // Krasnoyarsk worker. 1920.19 February. S. 2.

Children's defectiveness, crime and homelessness. According to the materials of the First All-Russian Congress 24.VI - 2.VII 1920 Moscow, 1920.

Zhdanov V. Help for children to the refugees //. 1922. No. 4.

Zenzinov Vladimir M. Homeless.

Irina Pavlova, Tatyana Katsina. The right to help: the development of legislation on social assistance during the period of the Provisional Government (March - October 1917) // 2017. No. 8. P. 55;

Irina Pavlova, Tatyana Katsina. Social policy of the Provisional Government: ideas and implementation experience (March - October 1917) // Tomsk State University Bulletin. 2018.No 428. C. 138.

Kudimov A.F. Historical background on the creation and organization of prisons for juvenile offenders // Actual problems of the execution of criminal punishments for minors. Vol. 11.M., 2000.S. 21.

A Family in the USSR. 1917-1967.

Kufaev V.I. Pedagogical measures to combat juvenile delinquency., 1927

I. Young offenders. - M., 1929;

I. Fighting crime in childhood and youth (socio-legal essays).

Makarenko On education. Moscow 1988.

S. Pedagogical works. Moscow, 1948;

U. The fight against homelessness and juvenile delinquency and its immediate tasks in the Siberian Territory. 
. The policy of social control of juvenile delinquency in the USSR (1917 end of the 1980s) //. - 2005 .-- T. 3 (2). - S. 223-240.. Homeless: Sociology. Gen. Work practice; Moscow, 1925.

I. Poverty and homelessness of minors.

S. Social disasters in Siberia: famine and epidemics in the 20-30s of the twentieth century., 2007.

Six months of Soviet power in the Yenisei province. Overview of the activities of Soviet institutions from January to August 1, 1920. P. 161.

Resolution of the People's Commissariat of the RSFSR, People's Health of the RSFSR, People's Commissariat of the RSFSR of July 30, 1920

"Instructions to the Commission on Juvenile Affairs." URL:

http://www.consultant.ru.

Resolution of the People's Commissariat of Justice of 12.12.1919

"Guidelines for the Criminal Law of the RSFSR" (Article 13). URL:

http://www.consultant.ru;

I. "Bourgeois specialists" in Siberia in the 1920s and early 1930s (social and legal status and working conditions)., 1999.

V. Children's homelessness and crime in the 1920s. (based on materials from the Upper Volga)., 1999.

A. The Beginning of Formation of a Legal Framework for Combating Child Homelessness and Neglect in Russia in the First Years of Soviet Power // News of Altai State. un-that. 2009. No. 4-4. S. 230.

F. Prevention of homelessness of children and adolescents in Russia (2090s of the XX century) (dissertation of the candidate, Vladimir Pedagogical University ((Vladimir), 1998).

Saved by the revolution. The fight against homelessness in the Irkutsk province and district (1920-1931) / comp. G.V., 1977.S. 7.

Handbook on the issues of social and legal protection of minors and children's defectsd, [1924].

A. Legal and organizational framework for the execution of criminal sentences of imprisonment of minors in the pre-war period (1917-1941) (dissertation of the candidate, Rostov Law Institute of the Ministry of Internal Affairs of the Russian Federation), 2009 ) 